\title{
Vertical ozone measurements in the troposphere over the Eastern Mediterranean and comparison with Central Europe
}

\author{
P. D. Kalabokas ${ }^{1}$, A. Volz-Thomas ${ }^{2}$, J. Brioude ${ }^{3}$, V. Thouret ${ }^{4}$, J.-P. Cammas ${ }^{4}$, and C. C. Repapis ${ }^{1}$ \\ ${ }^{1}$ Academy of Athens, Research Center for Atmospheric Physics and Climatology, Athens, Greece \\ ${ }^{2}$ Institut fuer Chemie and Dynamik der Geosphaere, Forschungszentrum Juelich, Germany \\ ${ }^{3}$ NOAA, Earth System Research Laboratory CSD, Boulder, Colorado, USA \\ ${ }^{4}$ Laboratoire d'Aerologie, UMR 5560, Universite Paul Sabatier, Toulouse, France
}

Received: 12 December 2006 - Published in Atmos. Chem. Phys. Discuss.: 15 February 2007

Revised: 27 June 2007 - Accepted: 17 July 2007 - Published: 23 July 2007

\begin{abstract}
Vertical ozone profiles measured in the period 1996-2002 in the framework of the MOZAIC project (Measurement of Ozone and Water Vapor by Airbus in Service Aircraft) for flights connecting Central Europe to the Eastern Mediterranean basin (Heraklion, Rhodes, Antalya) were analysed in order to evaluate the high rural ozone levels recorded in the Mediterranean area during summertime. The 77 flights during summer (JJAS) showed substantially (10$12 \mathrm{ppb}, 20-40 \%$ ) enhanced ozone mixing ratios in the lower troposphere over the Eastern Mediterranean frequently exceeding the $60 \mathrm{ppb}, 8$-h EU air quality standard, whereas ozone between $700 \mathrm{hPa}$ and $400 \mathrm{hPa}$ was only slightly (3$5 \mathrm{ppb}, 5-10 \%$ ) higher than over Central Europe. Analysis of composite weather maps for the high and low ozone cases, as well as back-trajectories and vertical profiles of carbon monoxide, suggest that the main factor leading to high tropospheric ozone values in the area is anticyclonic influence, in combination with a persistent northerly flow in the lower troposphere during summertime over the Aegean. On the other hand the lowest ozone levels are associated with lowpressure systems, especially the extension of the Middle East low over the Eastern Mediterranean area.
\end{abstract}

\section{Introduction}

Tropospheric ozone gained attention 2-3 decades ago, when it was realized that increasing surface ozone levels observed in urban areas and at rural sites were attributable to enhanced photochemical production in the troposphere (Volz and Kley, 1988; Staehelin et al., 1994). Subsequently, research programs and extended monitoring networks provided a reasonably comprehensive picture of the spatial distribution of surface ozone in Northern and Central Europe, whereas a

Correspondence to: P. D. Kalabokas

(kalabokas_pavlos@yahoo.gr) lack of ozone measurements was noted to persist for the Mediterranean region and especially the Eastern part was much less studied till the mid-1990s, (Beck and Grennfeld, 1993; Scheel et al., 1997). The analysis of ozone measurements made around Athens and at a rural site in Central Greece (Varotsos et al., 1993; Kalabokas and Bartzis 1998; Kalabokas et al., 2000; Kalabokas and Repapis, 2004) revealed fairly high rural ozone levels; around $60 \mathrm{ppb}$ during summer. This picture was confirmed by continuous measurements on the island of Crete (Kouvarakis et al., 2000) as well as measurements made during campaigns over the Aegean (Kourtidis et al., 2002; Kouvarakis et al., 2002; Lelieveld et al., 2002; Roelofs et al., 2003). The weather conditions over the Eastern Mediterranean during summer are influenced by eastward extensions of the Azores anticyclone and the low pressure branch of the large South Asian thermal low. Modelling studies of the large-scale dynamics (Rodwell and Hoskins, 1996; Rodwell and Hoskins, 2001) also suggest a strong influence of the Indian Monsoon on the dry Mediterranean climate in summer, i.e. by Rossby wave interaction with the southern flank of the midlatitude westerlies producing adiabatic descent and hence anticyclonic conditions at the surface over the Western Mediterranean. The resulting monsoon circulation over the Aegean Sea together with the strong pressure gradient, due to the surrounding mountains of the Greek peninsula in the West and the Anatolian plateau in the East, produces persistent northerly winds, the so called "Etesian winds" (annual winds). This flow of the low troposphere is most pronounced at the $850 \mathrm{hPa}$ level (Repapis et al., 1977). As a result, the Eastern Mediterranean is influenced by advection from Europe in the lower troposphere associated with the Etesian winds and subsidence in the middle and upper troposphere associated with the westerly flow in the descending branches of the Asian thermal low and, to a lesser extent, of the East African monsoon. It was also shown that the day-to-day variations in these two main factors are linked to the Asian monsoon (Rodwell and Hoskins

Published by Copernicus Publications on behalf of the European Geosciences Union. 
(a)

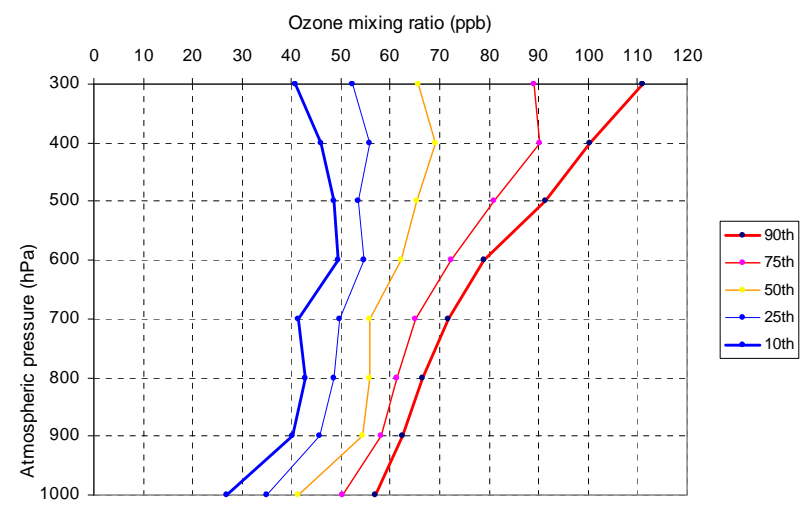

(b)

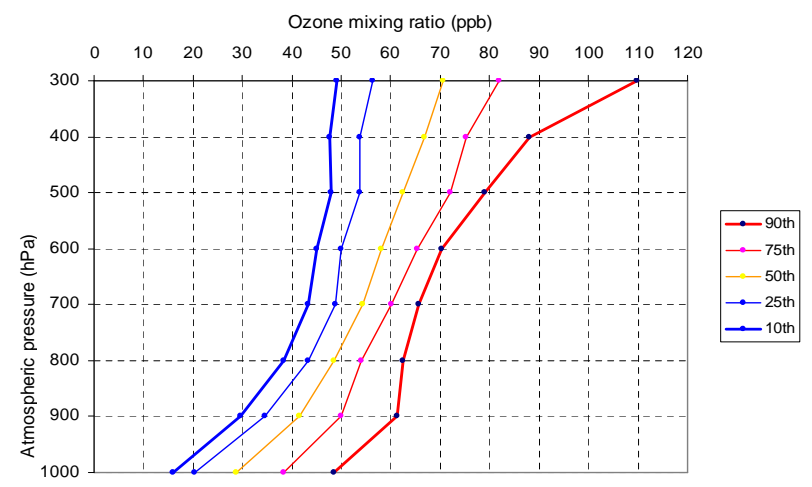

Fig. 1. Distribution statistics of summer (JJAS) vertical ozone averages at the standard pressure levels: (a) in the Eastern Mediterranean (77 profiles) and (b) in Central Europe (75 profiles).

2001; Lelieveld et al., 2002; Ziv et al., 2004).

The possibility for an influence of long range transport from the European continent, North America and Southeast Asia on ozone and its precursors over the Eastern Mediterranean has been discussed in several publications containing the results of two intensive measuring campaigns over the Aegean (MINOS and PAUR), which took place during recent years (e.g. Van Aalst et al., 1996; Lelieveld et al., 2002; Zerefos et al., 2002; Kourtidis et at., 2002; Kouvarakis et al., 2002; Gros et al., 2003; Roelofs et al., 2003; Sheeren et al., 2003; Traub et al., 2003; Volz-Thomas et al., 2003) The main results of the MINOS campaign (Lelieveld et al., 2002; Gros et al., 2003; Roelofs et al., 2003; Sheeren et al., 2003; Traub et al., 2003) regarding the primary and secondary trace gas concentrations of the lower and the middle troposphere of the Eastern Mediterranean were that in the boundary layer air quality standards regarding ozone are exceeded throughout the region, caused by West and East European pollution advected from the north. According to the main results of the PAUR campaign (Zerefos et al., 2002; Kourtidis et at.,
2002; Kouvarakis et al., 2002) concerning lower tropospheric ozone, long-range transport is the main factor contributing to enhanced ozone levels both at ground level and in the free troposphere and modelling results show that reductions of local emissions have little influence on ozone levels. In addition to the above observations, recent measurement and modelling studies suggest that polluted air masses exported from Switzerland towards the Mediterranean in summer exhibit high ozone production rates (Henne, 2005).

The aim of this work is to further investigate the high summer rural ozone levels in the boundary layer around Athens and the Aegean Sea, using vertical ozone profiles collected over the Eastern Mediterranean within the MOZAIC project (Marenco et al., 1998; Thouret et al., 1998; Sauvage et al., 2005; Thouret et al., 2006) during flights connecting the Eastern Mediterranean and Central Europe. These MOZAIC profiles constitute the largest data-set of summer-time vertical ozone measurements in the area. A parallel examination of the Eastern Mediterranean profiles with the Central European profiles was undertaken in order to examine the possible influence on the Eastern Mediterranean ozone concentrations throughout the troposphere of the summer Eastern and Central European atmospheric outflow towards the Eastern Mediterranean area (long-range transport of ozone and its precursors in the area or the subsidence of ozone-rich upper tropospheric layers to the boundary layer). Finally, in order to assess the role of meteorology on the tropospheric ozone levels, attention was given on the analysis of the characteristic meteorological conditions, in both regions, of the days with the highest and the lowest ozone mixing ratios, respectively.

\section{Results and discussion}

Since 1994, within the framework of the MOZAIC program (Marenco et al., 1998) five commercial airliners have been equipped with instruments to measure ozone, water vapour, and carbon monoxide (since 2002). One aircraft carries an additional instrument to measure total odd nitrogen (since 2001). Measurements are taken from take-off to landing. Based on the dual-beam UV absorption principle (Thermo-Electron, Model 49-103), the ozone measurement accuracy is estimated at $\pm[2 \mathrm{ppbv}+2 \%]$ for a $4 \mathrm{~s}$ response time (Thouret et al., 1998). Based on an infrared analyser, the carbon monoxide measurement accuracy is estimated at \pm 5 ppbv $\pm 5 \%$ (Nedelec et al., 2003) for a 30 s response time. The MOZAIC data base (http://mozaic.aero.obs-mip. $\mathrm{fr} / \mathrm{web} /$ ) was screened for summer flights between Central Europe and the northern part of the Eastern Mediterranean basin. In total, ozone profiles from 77 flights exist: 26 to Heraklion $\left(35.3^{\circ} \mathrm{N}, 25.2^{\circ} \mathrm{E}\right), 14$ to Rhodes $\left(36.4^{\circ} \mathrm{N}, 28.1^{\circ} \mathrm{E}\right)$ and 37 to Antalya $\left(36.8^{\circ} \mathrm{N}, 30.8^{\circ} \mathrm{E}\right)$. The departing Central European airport for most flights was Vienna $\left(48.1^{\circ} \mathrm{N}\right.$, $\left.16.6^{\circ} \mathrm{E}\right)$ in addition to 6 flights from Frankfurt $\left(50.1^{\circ} \mathrm{N}\right.$, 
8.5 E). The flights cover the period 1996-2002 and took place between June and September, almost exclusively during weekends. Both ascent and descent data have been used. Concerning the distribution of the profiles, most of them (28) took place in the year 1996, while in 1998 and in 2000 (years with severe forest fires in Greece) only two profiles were taken. For the remaining years $(1997,1999,2001,2002)$ 10-13 profiles were recorded for the June-September period. Finally, only one third of the profiles took place during the period 1998-2001, which was warmer than the years 1996, 1997 and 2002.

\subsection{Average ozone profiles}

For the following analysis the ozone profiles collected over the Mediterranean and the corresponding profiles over Vienna or Frankfurt were averaged over intervals of $100 \mathrm{hPa}$ (50 hPa for the lowest and highest levels): 1000 (1000-950), 900 (950-850), 800 (850-750), 700 (750-650), 600 (650$550), 500(550-450), 400(450-350)$ and $300(350-300) \mathrm{hPa}$.

The first step will be the determination of the average summer ozone values throughout the troposphere for both regions. Figure 1 displays median, 75 and 90 percentiles of the frequency distributions of the average ozone values for each pressure level over the Eastern Mediterranean (Heraklion, Rhodes and Antalya) and the corresponding values obtained over Central Europe (Vienna and Frankfurt) from the same flights. Table 1 summarises the differences between the average ozone profiles collected over Central Europe and the Eastern Mediterranean. In both regions the 90 percentiles exceed the $60 \mathrm{ppb}$ threshold at the 900 and $800 \mathrm{hPa}$ levels. In the Eastern Mediterranean, even the 75 percentiles are still around $60 \mathrm{ppb}$, about $10 \mathrm{ppb}$ higher than over Central Europe. The median value over the Eastern Mediterranean is about $55 \mathrm{ppb}$ between 900 and $700 \mathrm{hPa}$ (Fig. 1a). Over Central Europe, the median at $700 \mathrm{hPa}$ is similar (55 ppb) whereas significantly lower median values ( $42 \mathrm{ppb})$, are observed in the lower levels (Fig. 1b). Clearly, the differences in ozone mixing ratios between the two regions are more pronounced in the boundary layer (9-12 ppb higher ozone values in the Eastern Mediterranean, whereas only 3-5 ppb higher ozone mixing ratios are observed in the middle troposphere). The picture remains unchanged when the flights to Antalya are excluded from the analysis. Antalya is located outside the Aegean channel deep in a gulf surrounded by high mountains and was not expected to be influenced the same way by the predominant summer northern flow as the other two airports. The results in Fig. 1 and Table 1 suggest that boundary layer processes should be responsible for the enhanced surface ozone levels over the Mediterranean in comparison to Central Europe, which could be combined with results reported in the literature arguing that lower tropospheric ozone over the Eastern Mediterranean region is strongly influenced by precursor emissions from Eastern Europe, remaining in
Table 1. Average difference in ozone (in ppb) between Central Europe (Vienna, Frankfurt) and the Eastern Mediterranean (Heraklion, Rhodes, Antalya) for summer (JJAS). Relative differences (in percent) are given in parenthesis.

\begin{tabular}{ll}
\hline $\begin{array}{l}\text { Standard Pressure } \\
\text { Levels hPa }\end{array}$ & $\begin{array}{l}\text { Eastern Mediterranean - } \\
\text { Central Europe (77 profiles) } \\
\mathrm{ppb}(\%)\end{array}$ \\
\hline 1000 & $12.2(40.1)$ \\
900 & $9.4(22.0)$ \\
800 & $5.9(12.1)$ \\
700 & $3.6(6.6)$ \\
600 & $5.3(9.1)$ \\
500 & $4.9(7.8)$ \\
400 & $4.1(6.0)$ \\
\hline
\end{tabular}

Table 2. Comparison of ozone averages between Central Europe (Vienna, Frankfurt) and the Eastern Mediterranean (Heraklion, Rhodes, Antalya) for the highest and lowest $25 \%$ of ozone concentrations at $900 \mathrm{hPa}$ in the Eastern Mediterranean (19 profiles in each group).

\begin{tabular}{lll}
\hline $\begin{array}{l}\text { Standard } \\
\text { Pressure } \\
\text { Levels } \\
\mathrm{hPa}\end{array}$ & $\begin{array}{l}\text { Average }( \pm \mathrm{sd}) \text { ozone of } \\
\text { the highest 25\% cases in } \\
\text { Eastern Mediterranean } \\
\text { (corresponding values in } \\
\text { Central Europe for the } \\
\text { same flights) } \\
\text { ppb }\end{array}$ & $\begin{array}{l}\text { Average }( \pm \mathrm{sd}) \text { ozone of } \\
\text { the lowest 25\% cases in } \\
\text { (corresponding values in } \\
\text { Central Europe for the } \\
\text { same flights) } \\
\text { ppb }\end{array}$ \\
\hline 1000 & $\begin{array}{l}51.7 \pm 8.8(38.4 \pm 13.7) \\
600\end{array}$ & $36.7 \pm 7.3(24.9 \pm 11.2)$ \\
800 & $62.0 \pm 9.6(49.6 \pm 12.8)$ & $40.0 \pm 4.3(36.2 \pm 7.6)$ \\
700 & $64.6 \pm 12.4(59.3 \pm 7.4)$ & $46.6 \pm 6.6(42.6 \pm 7.6)$ \\
600 & $67.9 \pm 9.2(64.0 \pm 9.5)$ & $55.8 \pm 8.4(48.9 \pm 7.8)$ \\
500 & $75.7 \pm 14.5(65.4 \pm 8.4)$ & $61.6 \pm 15.2(53.3 \pm 10.2)$ \\
400 & $85.2 \pm 18.7(73.4 \pm 18.4)$ & $66.5 \pm 22.2(63.8 \pm 14.9)$ \\
\hline
\end{tabular}

the boundary layer, and from Western Europe in and directly above the boundary layer (Lelieveld et al., 2002).

In order to investigate the influence of the prevailing meteorological situation on the enhanced ozone values in the Aegean boundary layer, two groups of profiles were selected for further analysis: a) the quartile with the highest ozone values in the Eastern Mediterranean boundary layer (19 profiles) and b) the quartile with the lowest ozone values in the Eastern Mediterranean boundary layer (19 profiles). The average ozone values for these two groups as well as their corresponding values in Central Europe are presented in Table 2. It is observed that the average ozone concentrations in the lower troposphere $(700-900 \mathrm{hPa}$ ) for the highest ozone days in the Central Mediterranean are at $60-65 \mathrm{ppb}$ while for the lowest ozone days the average ozone values in the Eastern Mediterranean are at 40-50 ppb. 


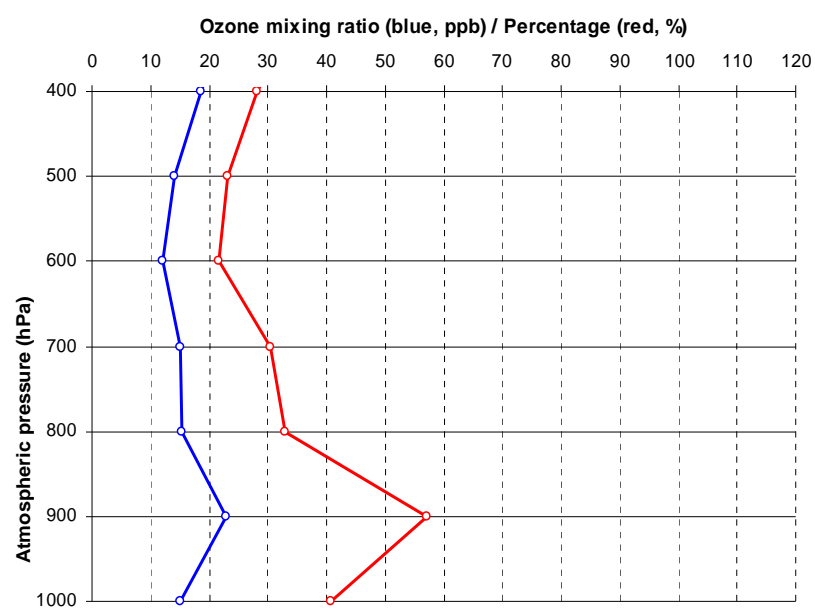

Fig. 2. Average vertical ozone summer (JJAS) absolute (blue, in $\mathrm{ppb}$ ) and relative (red, in \%) ozone differences in the Eastern Mediterranean (Heraklion-Rhodes-Antalya) between the $25 \%$ of the days with the highest ozone values at $925 \mathrm{hPa}$ and the $25 \%$ of the days with the lowest ozone values (19 profiles in each group).

In Figure 2 the absolute and relative increases of ozone (in \%) at the various pressure levels between the low ozone and the high ozone days in the Eastern Mediterranean are plotted. Summarising from that figure, the MOZAIC profiles for the Eastern Mediterranean region show that significantly higher ozone levels persistently prevail throughout the entire tropospheric column for the "high ozone days" profiles. The most pronounced difference between the high and the low ozone days is observed at the $900 \mathrm{hPa}$ level.

\subsection{Composite weather maps}

Figure 3 shows composite $925 \mathrm{hPa}$ weather maps for each group of profiles (high and low ozone days in the Eastern Mediterranean). The composite weather maps (average pressure fields of selected days) were constructed from the NCEP/NCAR reanalysis, based on grids of $2.5 \times 2.5 \mathrm{de}-$ grees, for the days of the flights in each group following the procedure of Kalnay et al., 1996. The composite weather map (Fig. 3a) for the highest quartile of ozone values in the Eastern Mediterranean (EMED) boundary layer shows weak anticyclonic systems over the Central Mediterranean and over the Balkans inducing stagnant conditions. A wellestablished northern current occurs in the boundary layer over the Aegean due to the combined influence of the Central Mediterranean and the Balkan highs with the Middle East low-pressure system. High surface air temperatures are also recorded in the area during this group of days. The average $900 \mathrm{hPa}$ ozone value in Eastern Mediterranean is $63 \mathrm{ppb}$ with little variability (Table 2, second column). The corresponding $900 \mathrm{hPa}$ average value in Central Europe is about $50 \mathrm{ppb}$ where a rather strong westerly airflow driven by the Scandi-
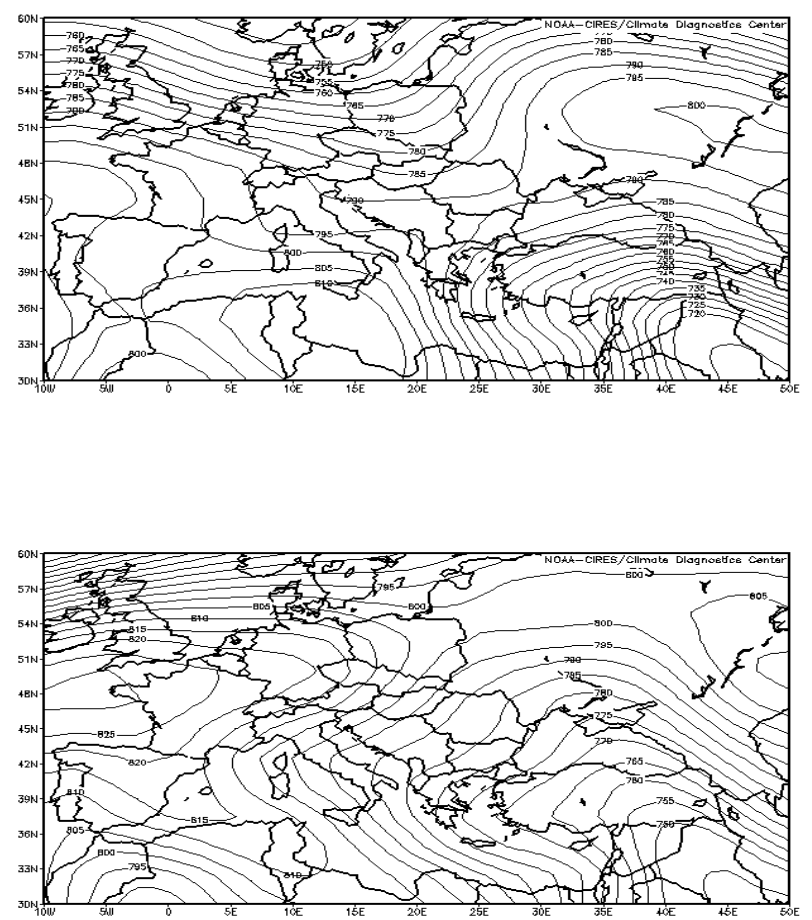

Fig. 3. Composite weather maps of geopotential heights at $925 \mathrm{hPa}$ : (a) for the group of the $25 \%$ cases with highest ozone values at $900 \mathrm{hPa}$ (upper panel), and (lower panel, (b) for the group of the $25 \%$ cases with the lowest ozone values at $900 \mathrm{hPa}$ in the Eastern Mediterranean (19 profiles in each group).

navian low occurs. The 13-15 ppb difference observed in the boundary layer between the Eastern Mediterranean and Central Europe is reduced to $3-5 \mathrm{ppb}$ in the $600-700 \mathrm{hPa}$ pressure levels resulted from the uniform westerly flow over the whole of Europe in the middle troposphere (not shown here). The lowest EMED boundary layer ozone levels ( $40 \mathrm{ppb}$ ) are recorded when the Middle East low-pressure system is extended to the Western Mediterranean with a weak gradient (Fig. 3b). Low ozone values are observed throughout the troposphere. It is known that contrary to the high pressure systems linked with clockwise subsidence of tropospheric air, the low pressure systems are linked with upward counterclockwise movement of air masses, raising in fact the boundary layer air into the free troposphere. This upward air movement is enhanced by the fact that the weak pressure gradients during Mediterranean summers are linked with vertical instability due to thermal convection (Ziv et al., 2004). From the above analysis it comes out that a key factor leading to high tropospheric ozone values in the Eastern Mediterranean but also in Central Europe is the anticyclonic influence. Summer anticyclones are rich in ozone as they transport downwards the upper troposphere ozone, which has a marked midsummer peak over Europe (Thouret et al., 2006). At the same time, the stable anticyclonic conditions are generally characterized by a pronounced mixing state and aging of boundary 
Table 3. Contribution of each atmospheric layer to the air arriving in Rhodes at $0-2 \mathrm{~km}$ on the high ozone days (4 cases) and on the low ozone days ( 5 cases) for 10-days and 5 days backward simulations.

\begin{tabular}{lllll}
\hline & $\begin{array}{l}\text { 10 days } \\
\text { High ozone }\end{array}$ & $\begin{array}{l}\text { 10 days } \\
\text { Low ozone }\end{array}$ & $\begin{array}{l}5 \text { days } \\
\text { High ozone }\end{array}$ & $\begin{array}{l}5 \text { days } \\
\text { Low ozone }\end{array}$ \\
\hline $0-2$ & $29.3 \%$ & $38.6 \%$ & $40.5 \%$ & $52.4 \%$ \\
$2-4$ & $25.6 \%$ & $33.6 \%$ & $29.2 \%$ & $38.8 \%$ \\
$>4$ & $45.1 \%$ & $27.8 \%$ & $30.3 \%$ & $8.8 \%$ \\
Total & $100 \%$ & $100 \%$ & $100 \%$ & $100 \%$ \\
\hline
\end{tabular}

layer air. The anticyclone over the Central Mediterranean entrains air masses to the Eastern Mediterranean region by the established northerly flow on the eastern side of the anticyclone. During the transport these air masses can be enriched with ozone precursors while passing over polluted areas of the continent. Eventually, this can lead to an accumulation of ozone over the Eastern Mediterranean region. In the Aegean the frequent presence of the Central Mediterranean and the Balkan high pressure systems in combination with the Middle-East low results in a persistent northerly flow in the boundary layer, frequently quite strong and containing high ozone amounts, which is in agreement with the results of short-term campaigns in the area (Lelieveld et al., 2002; Zerefos et al., 2002).

\subsection{Back-trajectories}

From our data-set, four cases from the quartile of the highest ozone values in the Eastern Mediterranean and five cases from the quartile of the lowest ones have been recorded during summer 2002. For that year some CO profiles from the MOZAIC project are also available. The meteorological conditions for the high and low ozone days in that particular year are similar to those of the entire data-set. Likewise, a significant difference of $20-25 \mathrm{ppb}$ is observed in the average ozone differences between high and low ozone days in the lower levels, which is maximized at $900 \mathrm{hPa}$ inside the boundary layer (Fig. 4), indicating that the selected subgroup of profiles is quite representative as similar ozone differences between high and low ozone days are observed also for the entire data-set.

For the determination of the air mass origin, the Lagrangian particle dispersion model FLEXPART (version 6.2; Stohl et al., 1998; Stohl et al., 2005) was used. FLEXPART was driven by model-level data from the European Centre for Medium-Range Weather Forecasts (ECMWF), with a temporal resolution of $3 \mathrm{~h}$ (analyses at 00:00, 06:00, 12:00, 18:00 UTC; 3-h forecasts at 03:00, 09:00, 15:00, 21:00 UTC), and 60 vertical levels. Horizontal resolution was $1^{\circ} \times 1 \times$ globally. 20000 particles were released from grid boxes $\left(0.5 \times 0.5^{\circ}, 100 \mathrm{~m}\right.$ in height $)$ centered on the

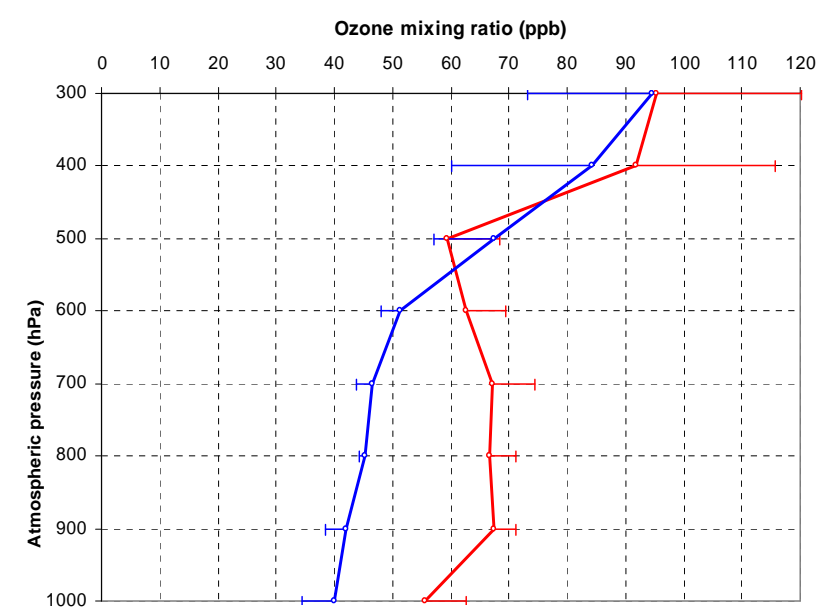

Fig. 4. Vertical ozone averages over Rhodes during the highest ozone days ( 4 cases, red line) and the lowest ozone days ( 5 cases, blue line) in summer 2002 .

MOZAIC profiles. The particles were advected backward in time over 10 days. Particles were transported both by the resolved winds and parameterized subgrid motions. FLEXPART parameterizes turbulence in the boundary layer and in the free troposphere by solving Langevin equations (Stohl and Thomson, 1999). FLEXPART uses also a parameterization scheme for convection (Forster et al., 2007). The residence times of particles were output every $3 \mathrm{~h}$ as 3 -h averages. They are available at a grid spacing of $1 \times 1^{\circ}$ in 3 layers between 0 and $2 \mathrm{~km}, 2$ and $4 \mathrm{~km}, 4$ and $20 \mathrm{~km}$. Percentage contribution of a geographical area to the chemical concentration of a box centered along a MOZAIC profile is calculated by dividing the total residence time of the 20000 released particles found in the area by the total residence time in the whole output grid over 10 days.

The backward trajectory simulations for the 4 cases of high ozone and the 5 cases of low ozone of the year 2002 in Rhodes are presented in Figs. 5 and 6 correspondingly. The percentage contribution of each geographical area separated in three atmospheric layers $(0-2 \mathrm{~km}, 2-4 \mathrm{~km}$ and $>4 \mathrm{~km})$ was calculated for the air parcels arriving at the $0-2 \mathrm{~km}$ layer over the Rhodes airport during the high and the low ozone cases (10-day backward simulation, Figs. 5-6). The corresponding percentage contribution of each atmospheric layer to the air arriving in Rhodes at $0-2 \mathrm{~km}$ on high and low ozone days, for the 10-days and 5 days backward FLEXPART simulations are shown in Table 3. For the 10-day trajectories about $55 \%$ of the air masses arriving at $0-2 \mathrm{~km}$ at Rhodes on the high ozone days come from altitudes below $4 \mathrm{~km}$, the contribution of this layer increases to $70 \%$ for 5 -days trajectories. From Table 3 it is also inferred that subsidence is a critical factor for the observed high ozone levels. In the 10-days for the lower altitudes $(0-2 \mathrm{~km})$ most of the contribution comes from the Aegean area and especially the Turkish coast with 


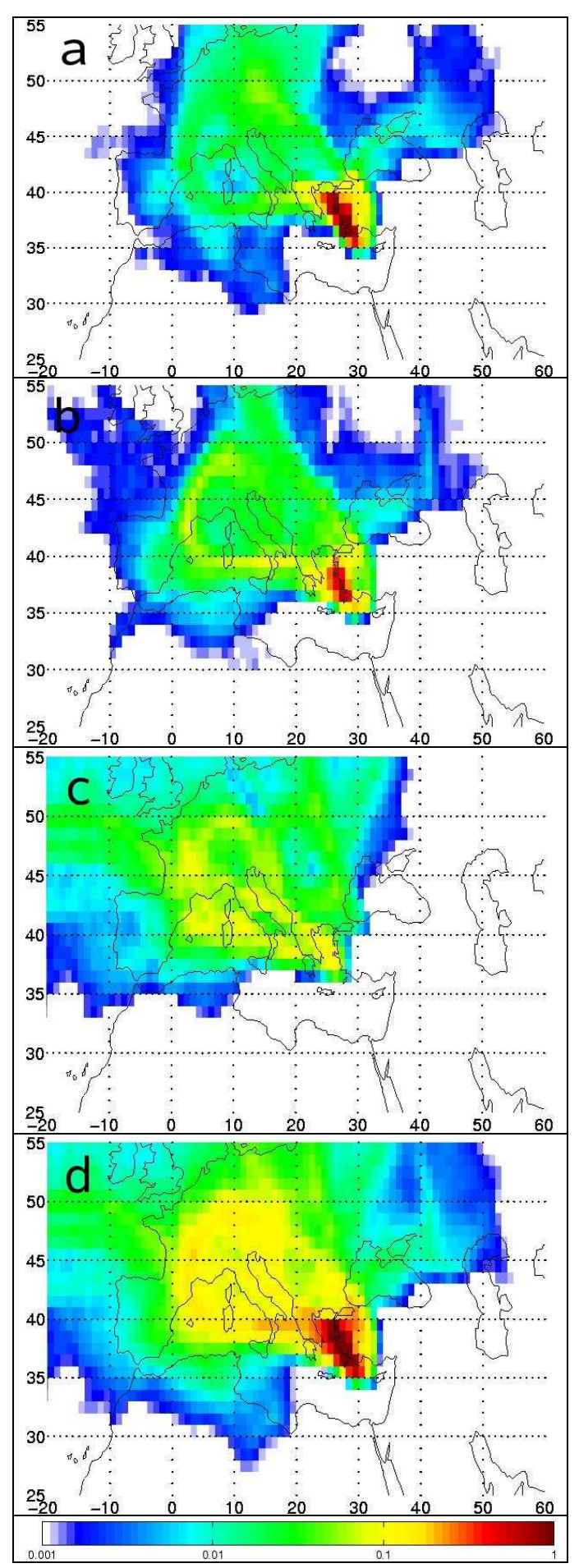

Fig. 5. Percentage contribution of geographical regions after 10days FLEXPART backward simulation for the 4 high ozone cases and for the 0-2 km air parcels arriving at Rhodes. (a) for the $0-2 \mathrm{~km}$ layer, (b) for the $2-4 \mathrm{~km}$ layer, (c) for the $>4 \mathrm{~km}$ layer and d) for the total atmospheric column.

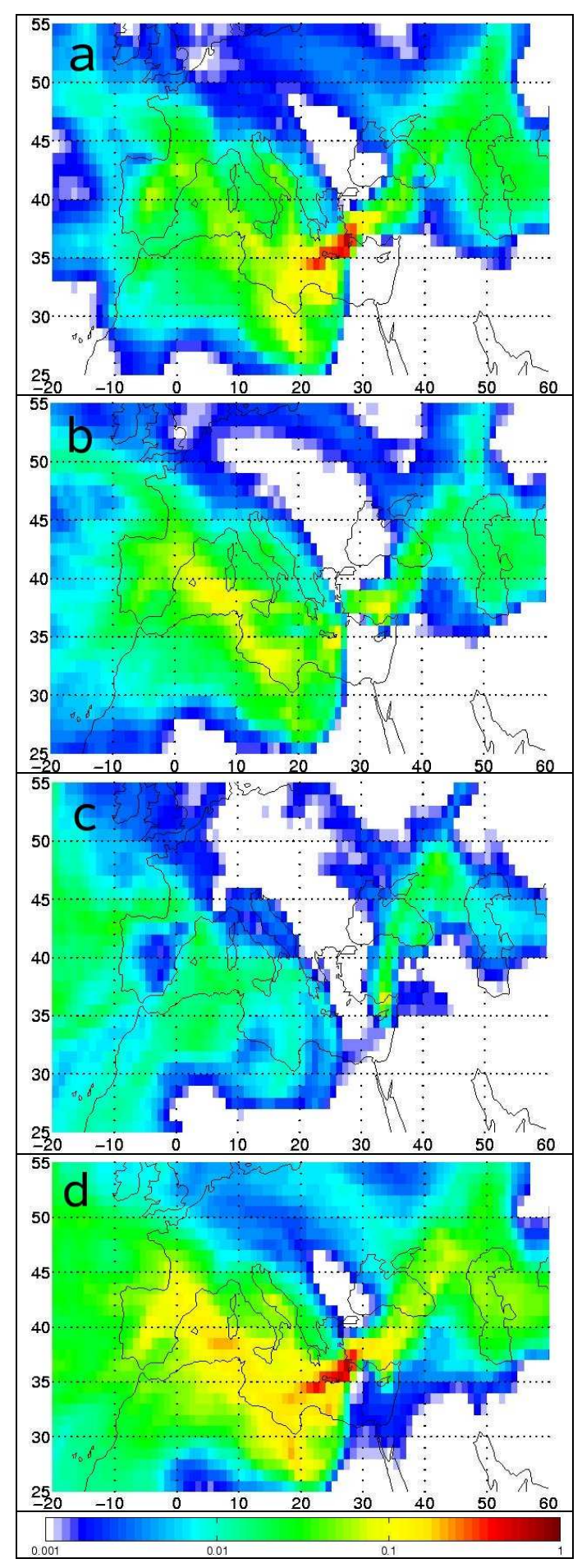

Fig. 6. Percentage contribution of geographical regions after 10days FLEXPART backward simulation for the 5 low ozone cases and for the $0-2 \mathrm{~km}$ air parcels arriving at Rhodes. (a) for the 0$2 \mathrm{~km}$ layer, (b) for the $2-4 \mathrm{~km}$ layer, (c) for the $>4 \mathrm{~km}$ layer and (d) for the total atmospheric column. 
a small contribution from Central Europe (Fig. 5). In the 2-4 km layer the contribution of the Aegean area is still significant but also a substantial contribution from the Balkans, Italy and Central Europe is visible. The above-described situation corresponding to high ozone days is quite frequent in the area and is also reported in the results of the MINOS and PAUR campaigns (Lelieveld et al., 2002; Zerefos et al., 2002).

The corresponding geographical contribution for the different atmospheric layers during the low ozone days for the 10-days FLEXPART backward trajectory simulations is shown in the Fig. 6. Most of the contribution comes from the lower layers of the Central and Eastern Mediterranean, advecting rather clean air to the measuring site, as it was also suggested by the composite weather maps. Table 3 shows clearly that for the low ozone days the contribution of the lower atmospheric layers is more significant than during high ozone days.

\subsection{Profiles of carbon monoxide}

From the MOZAIC project (Nedelec et al., 2003) and for the examined period in this study, $6 \mathrm{CO}$ profiles exist collected over Rhodes during summer 2002. The measured CO concentrations on high ozone days are significantly higher than on the low ozone days, especially in the boundary layer exceeding $150 \mathrm{ppb}$. This is in agreement with the results of the MINOS campaign, where CO levels higher than $150 \mathrm{ppb}$ are reported originating mainly from fossil fuel use and longrange transport from Western and Eastern Europe (Lelieveld et al., 2002).

\section{Conclusions}

Based on 77 MOZAIC flights recording vertical ozone profiles, the differences between Eastern Mediterranean and Central Europe showed significantly (10-12 ppb, 20-40\%) enhanced ozone levels over the Eastern Mediterranean for the $1000 \mathrm{hPa}$ to $900 \mathrm{hPa}$ levels, whereas ozone between $700 \mathrm{hPa}$ and $400 \mathrm{hPa}$ was only slightly (3-5 ppb, 5-10\%) higher than over Central Europe. The composite weather maps for the days with the highest ozone mixing ratios observed in the Mediterranean boundary layer suggest a strong influence of anticyclonic weather conditions. The lowest ozone levels are associated with a westward extension of the Middle East low and weak pressure gradients over the Eastern Mediterranean. Summer midlatitude anticyclones influence ozone in two ways: (i) downward transport from the upper troposphere and (ii) by creating stable conditions close to the surface, thereby hindering vertical dispersion of ozone precursors and enabling them to travel over long distances horizontally thus leading to regional photochemical activity in the boundary layer. Especially in the Aegean area, northern airflow due to the combined influence of the Central
Mediterranean and the Balkans anticyclones with the Middle East low predominates in the boundary layer, thus leading to southward transport of polluted air from the Balkans and Eastern Europe. The above arguments are supported by the results of backward trajectory simulations for days with high and low ozone mixing ratios and by the few $\mathrm{CO}$ profiles available for the Eastern Mediterranean. These findings come out from the analysis of the largest data set of summer vertical ozone profiles available for this area and confirm the results of short-term intensive campaigns in the region, reported in the literature.

Acknowledgements. This work was supported by the Research Committee of the Academy of Athens. The composite weather maps were provided by the NOAA/ESRL Physical Sciences Division, Boulder Colorado from their Web site at http://www.cdc.noaa.gov/. MOZAIC was funded by the European Commission.

Edited by: A. Stohl

\section{References}

Beck, J. and Grennfeld, P.: Distribution of ozone over Europe, in: the Proceedings of the EUROTRAC Symposium 92, edited by: Borell, P. M., Borell, P., Cvitas, T., and Seler, W., SPB Academic Publishing bv, 43-58, 1993

Forster, C., Stohl A., and Seibert P.: Parameterization of convective transport in a Lagrangian particle dispersion model and its evaluation, J. Appl. Met. Clim, 46, 403-422, doi:10.1175/JAM2470.1, 2007

Henne, S.: Characterisation of high Alpine pollution plumes, $\mathrm{PhD}$ Thesis, ETH Zurich (No 15949), 2005

Gros, V., Williams, J., van Aardenne, J. A., Salisbury, G., Hofmann, R., Lawrence, M. G., von Kuhlmann, R,. Lelieveld, J., Krohl, M., Berresheim, H., Lobert, J. M., and Atlas, E.: Origin of anthropogenic hydrocarbons and halocarbons measured in the summertime European outflow 10 (on Crete in 2001), Atmos. Chem. Phys., 3, 1223-1235, 2003

Kalabokas, P. D. and Bartzis, J. G.: Photochemical air pollution characteristics at the station of the NCSR-Demokritos, during the MEDCAPHOT-TRACE campaign, Greece (August 20thSeptember 20th, 1994), Atmosph. Environ., 32(12), 2123-2139, 1998.

Kalabokas, P. D., Viras L. G., Bartzis, J. G., and Repapis, C. C.: Mediterranean rural ozone characteristics around the urban area of Athens, Atmos. Environ., 34(29-30), 5199-5208, 2000

Kalabokas, P. D. and Repapis, C. C.: A climatological study of rural surface ozone in Central Greece, Atmos. Chem. Phys., 4, 1139 1147,2004

Kalnay, E., Kanamitsu, M., Kistler, R., Collins, W., Deaven, D., Gandin, L., Iredell, M., Saha, S., White, G., Woolen, J., Zhu, Y., Chelliah, M., Ebisuzaki, W., Higgins, W., Janowiak, J., Mo, K. C., Ropelewski, C., Wang, J., Leetmaa, A., Reynolds, R., Jenne, R., and Joseph, D.: The NCEP/NCAR Reanalysis 40-year Project. Bull. Am. Meteorol. Soc., 77, 437-471, 1996. 
Kourtidis, K., Zerefos, C., Rapsomanikis, S., Simeonov, V., Balis, D., Perros, P. E., Thomson, A. M., Witte, J., Calpini, B., Sharobiem, W. M., Papayannis, A., Mihalopoulos, N., and Drakou, R.: Regional levels of ozone in the troposphere over eastern Mediterranean, J. Geoph. Res., 107(D18), 8140, doi:10.1029/2000JD000140, 2002

Kouvarakis, G., Tsigaridis, K., Kanakidou, M., and Mihalopoulos, N.: Temporal variations of surface regional background ozone over Crete Island in the southeast Mediterranean, J. Geoph. Res., 105(D4), 4399-4407, 2000

Kouvarakis, G., Vrekoussis, M., Mihalopoulos, N., Kourtidis, K., Rappenglueck, B., Gerasopoulos E., and Zerefos, C.: Spatial and temporal variability of tropospheric ozone in the boundary layer above the Aegean Sea (eastern Mediterranean), J. Geoph. Res., 107(D18), 8137, doi:10.1029/2000JD000081, 2002

Lelieveld, J., Berresheim, H., Borman, S., et al.: Global air Pollution crossroads over the Mediterranean, Science, 298, 794-799, 2002

Marenco, A., Thouret, V., Nedelec, P., Smit, H., Helten, M., Kley, D., Karcher, F., Simon, P., Law, K., Pyle, J., Poschmann, G., Von Wrede, R., Hume, C., and Cook, T.: Measurements of ozone and water vapor by Airbus in-service aircraft: The MOZAIC airborne program, An overview, J. Geophys. Res., 103, 25 631-25 642, 1998

Nedelec, P., Cammas, J.-P., Thouret, V., Athier, G., Cousin, J.-M., Legrand, C., Abonnel, C., Lecoeur, F., Cayez, G., and Marizy, C.: An improved infrared carbon monoxide analyser for routine measurements aboard commercial Airbus aircraft: technical validation and first scientific results of the MOZAIC III programme, Atmos. Chem. Phys., 3, 1551-1564, 2003

Repapis, C., Zerefos, C., and Tritakis, B.: On the Etesians over the Aegean. Proc. Acad. Athens, 52, 572-606, 1977.

Rodwell, M. J. and Hoskins, B. J.: Monsoons and the dynamics of deserts, Q. J. R. Meteorol. Soc., 122, 1385-1404, 1996

Rodwell, M. J. and Hoskins, B. J.: Subtropical anticyclones and summer monsoons, J. Climate, 14, 3192-3211, 2001

Roelofs, G. J., Scheeren, H. A., Heland, J., Ziereis, H., and Lelieveld, J.: A model study of ozone in the eastern Mediterranean free troposphere during MINOS (August 2001), Atmos. Chem. Phys. 3, 1199-1210, 2003

Sauvage, B., Thouret, V., Cammas, J. -P., Gheusi, F., Athier, G., and Nedelec, P: Tropospheric ozone over Equatorial Africa: regional aspects from the MOZAIC data. Atmos. Chem. Phys. 5, 311$335,2005$.

Scheel, H. E., Areskoug, H., Geiß, H., Gomiscek, B., Granby, K., Haszpra, H., Klasinc, L., Kley, D., Laurila, T., Lindskog, A., Roemer, M., Schmitt, R., Simmonds, P., Solberg, S., and Toupance, G.: On the spatial distribution and seasonal variation of lower-troposphere ozone over Europe, J. Atmos. Chem, 28, 11-28, 1997

Sheeren, H. A., Lelieveld, J., Roelofs, G. J., Williams, J., Fischer, H., de Reus, M., de Gouw, J. A., Warneke, C., Holzinger, R., Schlager, H., Kluepfel, T., Bolder, M., van der Veen, C., and Lawrence, M.: The impact of monsoon outflow from India and Southeast Asia in the upper troposphere over the eastern Mediterranean, Atmos. Chem. Phys., 3, 1589-1608, 2003, http://www.atmos-chem-phys.net/3/1589/2003/.
Staehelin, J., Thudium, J., Buehler, R., Volz-Thomas, A., and Graber, W.: Trends in surface ozone concentrations at Arosa (Switzerland), Atmos. Environ., 28, 75-87, 1994

Stohl, A., Hittenberger, M., and Wotawa, G.: Validation of the Lagrangian particle dispersion model FLEXPART against largescale tracer experiments, Atmos. Environ., 24, 4245-4264, 1998

Stohl, A. and Thomson, D. J.: A density correction for Lagrangian particle dispersion models, Bound.-Layer Meteorol., 90, 155167, 1999

Stohl, A., Forster, C., Frank, A., Seibert, P., and Wotawa, G.: Technical note: The Lagrangian particle dispersion model FLEXPART version 6.2, Atmos. Chem. Phys., 5, 2461-2474, 2005

Thouret, V., Marenco, A., Logan, J., Nedelec, P., and Grouhel, C.: Comparisons of ozone measurements from the MOZAIC airborne program and the ozone sounding network at eight locations, J. Geophys. Res., 103, 25 695-25 720, 1998

Thouret, V., Cammas, J.-P., Sauvage, B., Athier, G., Zbinden, R., Nedelec, P., Simon, P., and Karcher ,F.: Tropopause referenced ozone climatology and inter-annual variability (1994-3003) from the MOZAIC programme, Atmos. Chem. Phys., 6, 1033-1051, 2006

Traub, M., Fisher, H., de Reus, M., Kormann, R., Heland, J., Ziereis, H., Schlager, H., Holzinger, R., Williams, J., Warnecke, C., de Gouw, J., and Lelieveld, J.: Chemical characteristics assigned to trajectory clusters during the MINOS campaign, Atmos. Chem. Phys. 3, 459-468, 2003

Van Aalst, R., Fowler, D., Megie, G., Moussiopoulos, N., Warneck, P., Volz-Thomas, A., Wayne, R.: in: "Photooxidants, Acidification and Tools; Policy Applications of EUROTRAC results" (Volume 10), edited by: Borrell, P., Hov, O., Grennfelt, P., and Builtjes, P., pp. 41-69, Springer Verlag, Berlin, Heidelberg, New York, 1996.

Varotsos, C., Kalabokas, P., and Chronopoulos, G.: Atmospheric ozone concentration at Athens, Greece. Part II: Vertical ozone distribution in the troposphere, Atmos. Res., 30, 151-155, 1993

Volz, A. and Kley, D.: Evaluation of the Montsouris series of ozone measurements made in the nineteenth century, Nature, 332, 240242, 1988.

Volz-Thomas, A., Beekmann, M., Derwent, D., et al.: Tropospheric ozone and its control, in: EUROTRAC-2 Final report, edited by: Midgley et al., Part 1, Margraf Verlag, Weikersheim, 2003.

Zerefos, C. S., Kourtidis, K. A., Melas, D., Balis, D., Zanis, P., Katsaros, L., Mantis, H. T., Repapis, C., Isaksen, I., Sundet, J., Herman, J,. Bhartia, P. K., and Calpini, B.: Photochemical Activity and Solar Ultraviolet Radiation (PAUR) Modulation factors: An overview of the project, J. Geophys. Res., 107(D18), 8134, doi:10.1029/2000JD00134, 2002

Ziv, B., Saaroni, H., and Alpert, P.: The factors governing the summer regime of the Eastern Mediterranean, Int. J. Climatol., 24, 1859-1871, 2004 